\title{
Spatial pattern analysis of land cover changes using Fragstat in Kendal Delta, Kendal Regency, Central Java
}

\author{
Nur Rizki Fitri Hastari ${ }^{1}$, Esya Rachma Ningrum ${ }^{1}$, Puspasari Setyowati ${ }^{1}$, Hayyun Nadia ${ }^{1}$, Qooi Insanu Putra ${ }^{1}$, Sofia \\ Lutfiana ${ }^{1}$, Muhammad Rois Akbar ${ }^{1}$, Heni Dwi Lestari ${ }^{1}$, Muhammad Fauzan Ramadhan ${ }^{2}$, Lucia Sandra Budiman ${ }^{2}$, and \\ Eko Haryono ${ }^{1 *}$ \\ ${ }^{1}$ Departement of Environmental Geography, Faculty of Geography, Universitas Gadjah Mada, 55281, Sleman, Yogyakarta, \\ Indonesia \\ ${ }^{2}$ Master Program in Geography, Faculty of Geography, Universitas Gadjah Mada, 55281, Sleman, Yogyakarta, Indonesia
}

\begin{abstract}
The northern coastal plains of Kendal Regency are deltaic landform whose processes are strongly influenced by fluvial (fluvial dominated deltas). The area of land in the Kendal Delta area continues to experience changes due to regional developments that occur as Kendal Regency is designated as one of the national activity center in terms of strategic and industrial economies. Various developments can trigger various land conversions so that studies are needed to identify changes occurring. The purpose of this study is to identify land cover patterns based on geomorphological aspects and analyzed land cover changes based on landscape structures in Delta Kendal in 1989 and 2021. Changes in the Kendal Delta landscape structure were analyzed using landscape metrics approach. The results showed that the land cover pattern in the Kendal Delta from 1989 to 2021 has a change. Based on the calculation from landscape metrics, land cover in Delta Kendal that has a relatively high patch density tends to have a high level of interference, and vice versa. In general, there is a relationship if there is an increase in the value of PD and ED, there will be a decrease in the value of MNN and IJI.
\end{abstract}

\section{Introduction}

The increase in population and the pressure of urban development causes the need for space to be greater and the use of land to increase [1]. Central Java Province has designated Kendal as one of the center of national activities that functions as a strategic economic and industrial area [2]. The development of urban areas causes the need for land to increase and land use changes occur [3]. Kendal Regency in 2012-2018 experienced physical development of the region causing land conversion in the form of residential and industrial land [4].

The northern coastal plain of Kendal Regency is a delta landform. The presence of the Quaternary fault causes the formation of a basin that has decreased, this basin is filled with deltaic and fluvial deposits (fluviodeltaic basin). The delta formed on the north coast of Kendal is a fluvial-dominated delta, which is a delta that is strongly influenced by fluvial landforms [5]. The delta ecosystem has an important role in maintaining environmental balance because it has great benefits from its very fertile physical properties due to the alluvial sedimentation process that carries high nutrients [6]. The flat morphology of the delta with a slope of 0$8 \%$ makes it easier to use land [7]. This flat morphology is used as settlements, swamps, shrubs, gardens, rainfed rice fields, irrigated rice fields, rivers, fields, and ponds [7]. In addition, Delta Kendal has a strategic position and has the potential to be developed for various uses such as industrial areas, tourism, aquaculture, and settlements.

Landscape structure is a pattern of landscape that is determined from the type of use and structure in the form of size, shape, arrangement and distribution of elements of the landscape [8]. Landscape elements can be defined as separate entities or referred to as 'patches', whereas landscape patterns are described as the use of metrics to measure patches (e.g. size, shape and isolation), mosaic (patch richness and connectivity diversity) and characteristics [9]. Patch can also be defined as the smallest unit of analysis that has homogeneous properties, such as rice fields, industrial areas [10]. The scale of analysis can be in the form of land cover, land use, soil and geomorphology.

Changes in use to built-up land are one of the characteristics of urbanization [11]. Uncontrolled land use changes will cause environmental, social, and economic problems [12]. Changes in land use that are not controlled and are not in accordance with environmental ethics will cause damage. One of the variables to determine changes in land use is to use land cover. Land cover can provide very important information for modelling and understanding natural phenomena that occur on the earth's surface [13]. Land cover information is obtained through data from remote sensing which can record land cover dynamics spatially and temporally. Analysis of the development of land

\footnotetext{
*Corresponding author: e.haryono@ugm.ac.id
} 
cover changes in an area can be done through the use of remote sensing data in the form of multitemporal satellite images [14]. Multitemporal land cover data can show patterns of land conservation over time.

Landscape metrics is a method used to analyze the growth of an area using remote sensing (PJ) and Geographic Information Systems (GIS) [15]. Landscape metrics can be used in landscape ecological assessments to support planning and decision making in landscape management [16] and can be used to measure landscape structure and structural complexity. Landscape metrics is a quantitative index that describes the compositional and spatial aspects of the landscape based on map data, remote sensing, and Geographic Information System analysis [9].

The landscape metrics method can be used to analyze many things, one of which is changes in land cover patterns [17]. According to [16], landscape metrics can help in understanding landscape changes from various perspectives (visual, ecological, and cultural). Metric analysis can be based on Area/Density/Edge metrics, Shape metrics, Core area metrics, Isolation/Proximity metrics, Diversity metrics, Evenness metrics, Connectivity metrics, Dominance metrics [18]. The landscaping metrics method used is able to easily describe the dynamics of changes in land cover patterns in more detail [17]. This study aims to identify land cover patterns based on geomorphological aspects and analyze land cover changes based on landscape structures in Delta Kendal.

\section{Methods}

\subsection{Research Location}

Kendal Regency is one of the regencies in Central Java Province which has 20 sub-districts. Kendal Regency is located between $60^{\circ} 32^{\prime}-70^{\circ} 24^{\prime}$ South Latitude and $109^{\circ} 40^{\prime}-110^{\circ} 18^{\prime}$ East Longitude. Administratively, it is bordered by the Java Sea in the north, Semarang City in the east, Semarang Regency in the southeast, Temanggung Regency in the south and Wonosobo Regency in the southwest and Batang Regency in the west (Fig 1.). Kendal Regency has an area of 100.233 Ha with the largest area being Singorojo District.

Topographic conditions in Kendal Regency are divided into three categories, namely mountainous areas, hilly areas and beaches. The mountainous area is located in the southern part of the district with an altitude between 0-2579 masl. The hilly area covers the central part of the district. Lowland areas and beaches are located in the northern part of the district with an altitude between 0-10 meters above sea level [19]. Kendal Regency consists of various landforms such as landforms from volcanic, fluvial and marine processes.

The location of this research was conducted in the coastal area of Kendal Regency which is a coastal delta. The Delta Coast is supported by four main watersheds, from East to West, namely the Blorong watershed, the Bodri watershed, the Damar watershed, and the Kuto watershed. Of the four watersheds, the largest and most dominant is the Bodri watershed. Therefore, the coast of
Kendal Regency is better known as the coast of the Bodri Delta. The research was conducted at this location because the development of the coastal morphology of the Bodri Delta is quite dynamic until now. There are several locations that experience abrasion (such as on the coast of Kartika Jaya) and there are those that experience accretion. Overall, the coast of the Bodri Delta, Kendal Regency tends to experience growth.

Changes in the shoreline of the coastal area of Kendal Regency during the period 1864 -1973 (109 years) experienced varied growth [20]. During this period, the Kendal Regency coast experienced developments that tended to move towards the East. The mouth of the Bodri River has also changed its position. Initially in 1864 the estuary of the Bodri River passed through the Margorejo area (west of the current Bodri River estuary), then in 1910 the estuary of the river had shifted to the East and experienced growth and its estuary branched.

This coastal development continued until 1946 where the direction of the Bodri River estuary had shifted to the North and Northeast. Furthermore, the mouth of the Bodri River continues to experience changes, namely in 1973 the river channel had two branches, one empties into the North and Northeast, the other empties into the Northwest until now. In some places it expands towards the sea (accretion) as a result of a fairly large sedimentation process, but in other places there are coastal areas that experience the opposite problem, namely abrasion, for example in the coastal area of Kartika Jaya.

\subsection{Research Method}

The research was conducted using quantitative methods that emphasize geographic information system techniques in its implementation. This research is descriptive quantitative where the analysis is described from the results of processing various numerical data to identify the characteristics and patterns of change of the phenomenon under study. Research is classified as deductive research, which is carried out by observing a phenomenon and then comparing it with existing theories. The final result of this research is to quantify the ecological structure of the coastal landscape in Kendal Regency. To realize these results, the stages of research that will be carried out are: (1) Inventory and Data Collection (2) Data Processing and (3) Data analysis.

\subsection{Research Data}

The data used are secondary data in the form of Landsat images and various spatial data which are described in detail in Table 1. Data collection was carried out by studying literature and downloading geospatial data openly (open source) on the United States Geological Survey (USGS) website, Center for Development and Geological Research, and the Geospatial Information Agency. Data processing is carried out using a number of software including ArcGIS, Fragstat, and Google Earth. 


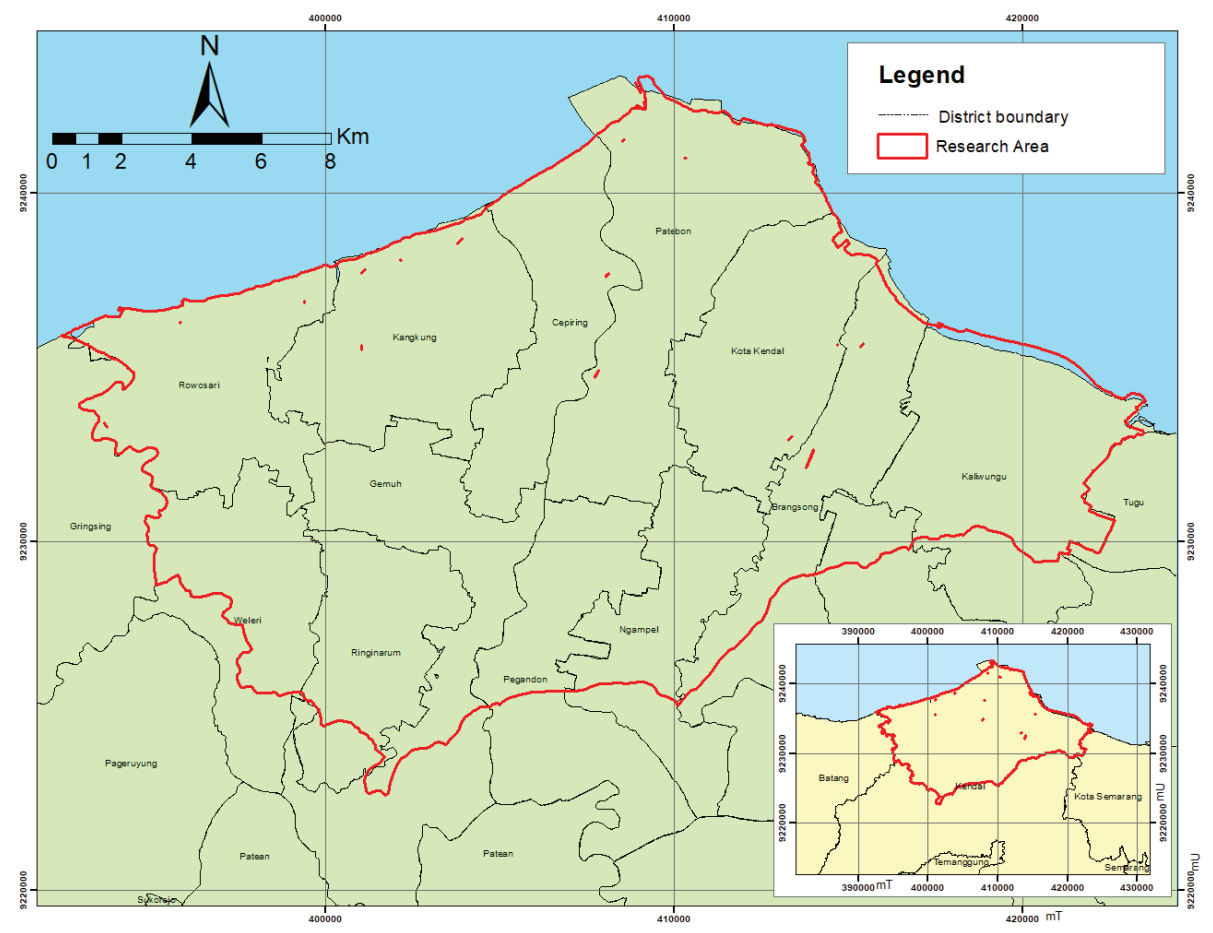

Fig. 1. Administration map of Delta Kendal, Kendal Regency

Table 1. Research Data

\begin{tabular}{|l|c|l|}
\hline \multicolumn{1}{|c|}{ Data } & Format & \multicolumn{1}{c|}{ Source } \\
\hline $\begin{array}{l}\text { Landsat Imagery 5 } \\
\text { TM 30 m resolution } \\
\text { in 1989 }\end{array}$ & Raster & $\begin{array}{l}\text { United States } \\
\text { Geological Survey }\end{array}$ \\
\hline $\begin{array}{l}\text { Landsat Imagery 8 } \\
\text { OLI 30 m resolution } \\
\text { in 2019 }\end{array}$ & Raster & $\begin{array}{l}\text { United States } \\
\text { Geological Survey }\end{array}$ \\
\hline $\begin{array}{l}\text { Google Earth } \\
\text { Imagery }\end{array}$ & Raster & Google Earth \\
\hline Alos Palsar Imagery & Raster & $\begin{array}{l}\text { United States } \\
\text { Geological Survey }\end{array}$ \\
\hline $\begin{array}{l}\text { Geological Map } \\
\text { Scale 1:100.000 }\end{array}$ & Vektor & $\begin{array}{l}\text { Geological Research } \\
\text { and Development } \\
\text { Center }\end{array}$ \\
\hline $\begin{array}{l}\text { Soil Type Map } \\
\text { Scale 1:100.000 }\end{array}$ & Vektor & $\begin{array}{l}\text { Agricultural Research } \\
\text { and Development } \\
\text { Agency of the Ministry } \\
\text { of Agriculture }\end{array}$ \\
\hline $\begin{array}{l}\text { Indonesia } \\
\text { Topographic Map } \\
\text { scale 1:25.000 }\end{array}$ & Vektor & $\begin{array}{l}\text { Geospatial Information } \\
\text { Agency }\end{array}$ \\
\hline
\end{tabular}

\subsection{Data Processing}

First steps of data processing are to make land cover maps in 1989 and 2021. The 1989 land cover map is the result of interpretation from the Landsat $5 \mathrm{TM}$ imagery with a resolution of 30 meters in 1989, while the 2021 land cover map is sourced from the 2019 Landsat imagery. Geometric and atmospheric correction for Landsat imagery was built using ArcGIS. Classification of land cover made by interpretation of composite band 754, where band 7 is SWIR-2 spectrum, band 5 is NIR spectrum, and band 4 is red spectrum. Satellite image visual interpretation based on spatial object recognition. Object characteristic recognized by elements of interpretation such as hue, color, shape, size, texture, shadow, pattern, and object appearance association.

Interpretation of landsat imagery used for validating land cover. The results of the interpretation of the Landsat imagery are then validated. Land cover map of 1989 validated by google earth imagery in 1989 . Meanwhile, land cover map of 2019 validated by field validation in May 2021. The validation land cover map of 2019 is based on sample points that have been made with stratified random sampling. Each land cover class has 10 sample points so that the total sample points are 330 points (Fig 2). The post-field stage is to make a land cover map for 2021 according to the validation results. Processing the data from the validation of the land cover using the confusion matrix. Processing of land cover change data in 1989 and 2021 was carried out using landscape metrics in the Fragstat software.

\subsection{Research Analysis}

The changes in the landscape structure of the Delta Kendal were analyzed using Fragstat software. The input data for the analysis of changes in the landscape structure of the Delta Kendal in Kendal Regency is a land cover map on the Delta Kendal landform in 1989 and 2021. The analysis of changes in landscape structure is carried out by analyzing patches on the Fragstat software using a number of landscape metric parameters including Edge Density (ED), Patch Density (PD), Mean Shape Index (MSI), Mean Nearest Neighbor (MNN), and Interspersion and Juxtaposition Index (IJI).

Edge Density (ED) is the sum of the lengths (m) of all edge segments involving the appropriate patch type, divided by the total landscape area (m2), multiplied by 10,000 (to convert to hectares) [21], with the formula as in equation 1 .

$$
\mathrm{ED}=\frac{\sum_{k=1}^{m \prime} e_{i k}}{A}(10,000)
$$




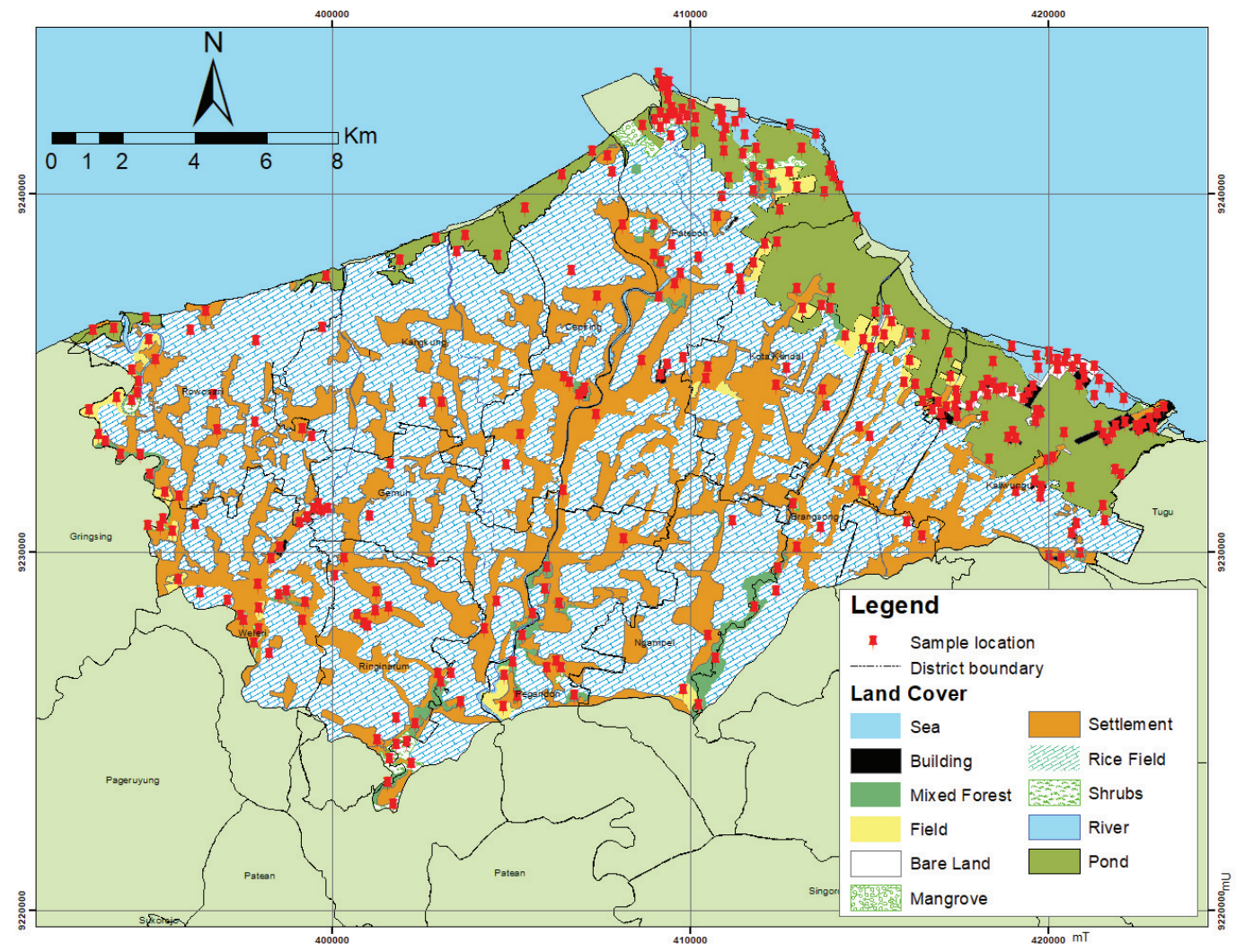

Fig. 2. Sample points map

Patch Density (PD) is the number of patches of the appropriate patch type (NP) divided by the total landscape area, multiplied by 10,000 and 100 (to convert to 100 hectares). The PD value can also be used as an index to the heterogeneity of a landscape formation [21], with the formula as in equation 2 .

$$
\mathrm{PD}=\frac{n_{i}}{A}(10,000)(100)
$$

Mean Shape Index (MSI) is the sum of each patch circumference divided by the square root of the patch area (hectare) for each patch class (class level) and adjusted to the standard polygon or square. Mean Nearest Neighbor (MNN) is the nearest neighbor distance from individual patches to similar patches, namely the class in each landform in meters. Meanwhile, the Interspersion and Juxtaposition Index (IJI) is a measure of the relative interspersion of each landform class.

\section{Result and Discussion}

\subsection{Accuracy Test of the Classification}

The accuracy test of the classification results was carried out to test the accuracy of the land cover map generated from the digital classification process with sample points from the field results. Based on the results of the confusion matrix calculation on the land cover map in 2021, the kappa value is 0.853 and the overall accuracy value is $86.74 \%$, proving that the land cover map is reliable and feasible. From 330 sample points, not all can be checked due to limited access. In general, land cover change in the field changed into settlement and industrial building growth in Kendal (Tabel 2).

\subsection{Land Cover Pattern Analysis}

Land cover from time to time continues to change due to land conversion (Fig. 3. and Fig. 4.). Figure 3 shows the land cover at Delta Kendal in 1989 was dominated by vegetation cover in the form of rice fields, fields, mixed forest, and shrubs. Figure 4 shows that in 2021 land cover in the Delta Kendal has experienced a change from the dominance of vegetation cover to built-up area which consists of construction and buildings. Table 3 explains the changes in the land cover area in Delta Kendal. In 1989, the largest land cover was rice fields with an area of $182.92 \mathrm{~km} 2$, followed by settlements, mixed forest, ponds, and fields which each had an area of $33.35,29.43,25.52$, and 23.02 .

Land cover decreases significantly are mixed forest, field, and shrubs. There are $50.63 \mathrm{~km} 2$ decreased. Meanwhile, Settlement is land cover that increased significantly, it is about $45,1 \mathrm{~km} 2$. The highest settlement increase happened in the District of Brangsong, Pegandon, Ngampel, Patebon, part of Kaliwungu, and Kendal City. Research results [4] shows that between 2007 - 2018 development of settlement areas in Brangsong, Patebon, Kaliwungu, and Kendal City are high enough. Industrial area growth is a sign of change from agricultural land to non-agricultural land [22] which is proved by Kendal Industrial Area (Kawasan Industri Kendal - KIK) growth in northern Kaliwungu District [23]. 
Tabel 2. Confusion matrix Calculation of Kendal Land Cover Map in 2021

\begin{tabular}{|c|c|c|c|c|c|c|c|c|c|c|c|c|c|}
\hline \multirow{2}{*}{\multicolumn{2}{|c|}{$\begin{array}{l}\text { Land } \\
\text { cover }\end{array}$}} & \multicolumn{10}{|c|}{ Observation } & \multirow{3}{*}{$\begin{array}{c}\begin{array}{c}\text { Classification } \\
\text { overall }\end{array} \\
31\end{array}$} & \multirow{3}{*}{$\begin{array}{c}\begin{array}{c}\text { User } \\
\text { accuracy }\end{array} \\
100 \%\end{array}$} \\
\hline & & \multirow{2}{*}{$\frac{\mathrm{A}}{31}$} & \multirow{2}{*}{$\frac{\mathrm{B}}{0}$} & \multirow{2}{*}{$\frac{\mathrm{C}}{0}$} & \multirow{2}{*}{$\frac{\mathrm{D}}{0}$} & \multirow{2}{*}{$\frac{\mathrm{E}}{0}$} & \multirow{2}{*}{$\frac{\mathrm{F}}{0}$} & \multirow{2}{*}{$\frac{G}{0}$} & \multirow{2}{*}{$\frac{\mathrm{H}}{0}$} & \multirow{2}{*}{ I } & \multirow{2}{*}{$\frac{\mathrm{J}}{0}$} & & \\
\hline \multirow{10}{*}{ 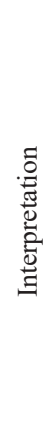 } & A & & & & & & & & & & & & \\
\hline & B & 0 & 40 & 0 & 0 & 0 & 0 & 0 & 2 & 0 & 0 & 42 & $95,24 \%$ \\
\hline & $\mathrm{C}$ & 0 & 0 & 28 & 1 & 0 & 0 & 0 & 1 & 0 & 0 & 30 & $93,33 \%$ \\
\hline & $\mathrm{D}$ & 0 & 0 & 0 & 42 & 0 & 4 & 1 & 2 & 1 & 0 & 52 & $80,77 \%$ \\
\hline & $E$ & 0 & 6 & 0 & 0 & 28 & 0 & 1 & 1 & 0 & 0 & 36 & $77,78 \%$ \\
\hline & $\mathrm{F}$ & 0 & 0 & 0 & 0 & 0 & 30 & 0 & 0 & 0 & 0 & 30 & $100 \%$ \\
\hline & $\mathrm{G}$ & 0 & 6 & 0 & 0 & 0 & 1 & 71 & 3 & 1 & 0 & 83 & $85,54 \%$ \\
\hline & $\mathrm{H}$ & 0 & 1 & 1 & 0 & 0 & 0 & 0 & 63 & 0 & 0 & 65 & $96,92 \%$ \\
\hline & I & 0 & 2 & 0 & 0 & 0 & 2 & 0 & 2 & 34 & 0 & 52 & $65,39 \%$ \\
\hline & $\mathrm{J}$ & 0 & 1 & 0 & 0 & 3 & 0 & 3 & 2 & 0 & 45 & 54 & $83,33 \%$ \\
\hline \multicolumn{2}{|c|}{$\begin{array}{l}\text { Truth } \\
\text { overall }\end{array}$} & 31 & 57 & 29 & 43 & 31 & 39 & 76 & 78 & 39 & 52 & 475 & \\
\hline \multicolumn{2}{|c|}{ Recall } & $100 \%$ & $70,18 \%$ & $96,55 \%$ & $97,67 \%$ & $90,32 \%$ & $76,92 \%$ & $93,42 \%$ & $80,77 \%$ & $87,18 \%$ & $87 \%$ & & \\
\hline \multicolumn{2}{|c|}{$\mathrm{OA}$} & $86,74 \%$ & & & & & & & & & & & \\
\hline \multicolumn{2}{|c|}{ Kappa } & 0,851 & & & & & & & & & & & \\
\hline
\end{tabular}

Information :

Information :
A : River
D : Field
G : Settlement
$\mathrm{J}:$ Shrubs
B : Building
E : Bare Land
$\mathrm{H}$ : Rice Field
$\mathrm{C}$ : Mixed Forest F : Mangrove
I : Pond

KIK development based on spatial plans of Kendal Regency of 2011 - 2031 as an effort to improve the regional economy in the eastern coastal area of Kendal Regency. High land cover change from production land to built-up land triggered by industrial and city growth in Kendal Regency.

In addition, land cover that experienced another significant increase was the increase in ponds by 12.61 $\mathrm{km} 2$. This increase was accompanied by a decrease in mangrove and rice fields. The largest increase in pond land is in the Patebon, Brangsong, Kaliwungu, and Kendal sub-districts caused by land suitability for pond activities. For example, in Brangsong District, the land suitability for shrimp and milkfish ponds in the S1 (Very Suitable) class is $39.68 \%$ and S2 (Sufficiently Appropriate), $60.32 \%$ of the total area [24]. Kendal District based on the results of research by [25] shows the suitability for a name shrimp aquaculture ponds due to the condition of the waters. Thus, the land cover pattern formed in the lower delta plain of Delta Kendal is formed following the suitability of the land owned.

Table 3. Land Cover Area of Delta Kendal in 1989 and 2021.

\begin{tabular}{|r|l|r|r|}
\hline \multirow{2}{*}{ No } & \multirow{2}{*}{ Land Cover } & \multicolumn{2}{|c|}{ Area $(\mathrm{km} 2)$} \\
\cline { 3 - 4 } & & Year 1989 & \multicolumn{1}{|c|}{ Year 2021 } \\
\hline 1 & Rice field & 182.92 & 179.00 \\
\hline 2 & Building & 1.53 & 2.19 \\
\hline 3 & Field & 23.02 & 6.00 \\
\hline 4 & Shrub & 11.77 & 1.64 \\
\hline 5 & Pond & 25.52 & 38.13 \\
\hline 6 & Mixed Forest & 29.43 & 5.95 \\
\hline 7 & Mangrove & 4.76 & 1.94 \\
\hline 8 & Settlement & 35.35 & 80.45 \\
\hline 9 & Bare land & 0.87 & 1.46 \\
\hline
\end{tabular}

\subsection{Landscape Metrics Analysis}

Land cover change analysis can also be done using landscape metrics analysis, which is to find out changes in fragments that dominate a landscape [26]. The matrix analysis used includes Patch Density (PD), Edge Density (ED), Mean Shape Index (MSI), Mean Nearest Neighbor (MNN), and Interspersion and Juxtaposition Index (IJI) as presented in Table 4. Temporal analysis to determine the dynamics of land cover change in the Delta Kendal in each landform.

Patch Density (PD) is an indicator of fragment area. A fragment is a homogeneous area that can be distinguished from the surrounding area [26]. The land cover in 1989 which had the highest PD value was a field of 0.127 but in 2021 it experienced the most significant decrease in PD value to 0.065 . In addition to the field that experienced a decrease in the value of PD is the mixed forest. This decrease indicates a decrease in the area of fragments triggered by a decrease in land area. The land cover that experienced a significant increase in the PD value was a settlement from 0.037 to 0.254 , which means that settlement experienced an increase in the area of the fragments. This is due to the sporadic growth of settlements. A fragmented matrix can cause an edge or edge area with a large area [26].

The land cover that experienced a significant decrease in the ED value was bare land, about 17,235. In 1989 the bare land had the highest ED value, but in 2021 it experienced the most significant decrease in the ED value, this is because the bare land experienced an uneven increase in area. These changes can affect changes in habitat biodiversity which can later affect changes in resources [26]. 


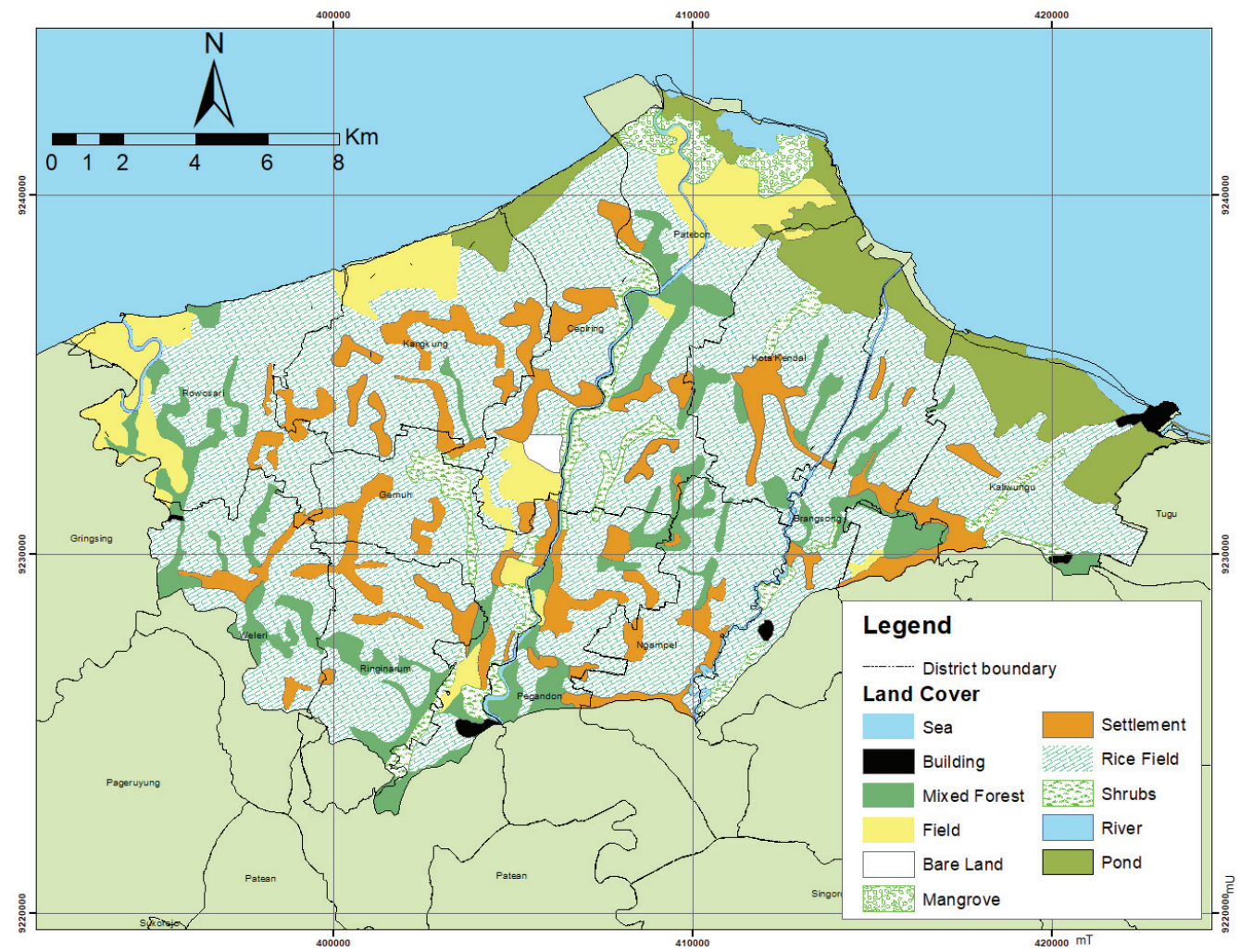

Fig. 3. Land Cover Map of Delta Kendal in 1989

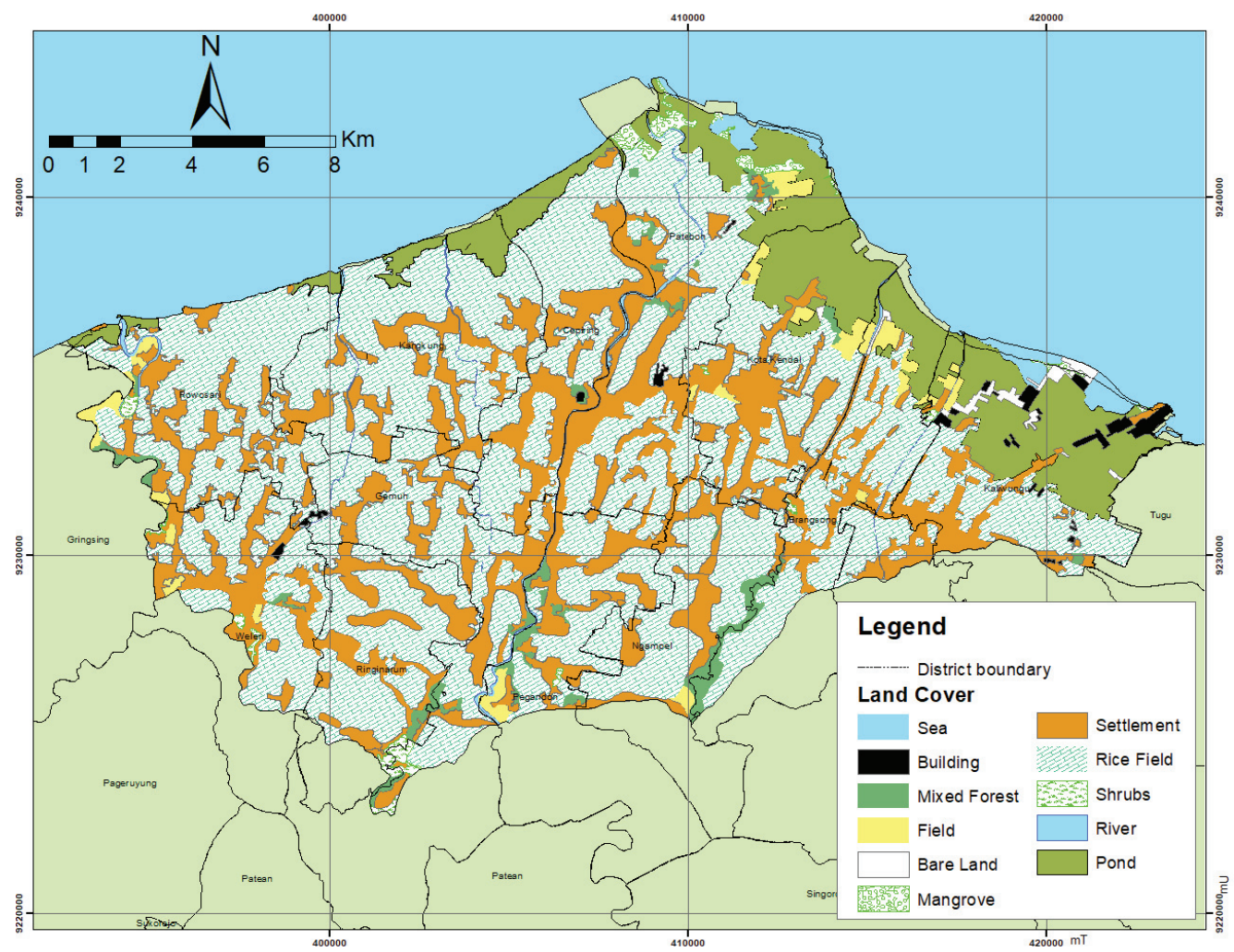

Fig. 4. Land Cover Map of Delta Kendal in 2021

The land cover that experienced a significant increase in the ED value was the rice field and settlement, this shows that the land cover has a fairly high edge density when viewed from the edge aspect [27]. A high ED value indicates that the edge area is very wide, which indicates that there is fragmentation or a change in structure from homogeneous to heterogeneous [26]. Fragmentation in rice fields occurs due to changes in rice field land into settlements, while fragmentation in settlements occurs due to the sporadic development of settlements.

The Mean Shape Index (MSI) is an indicator of the shape of the fragment. The shape of the patch becomes more regular if the MS value is close to 1 with a square or circle shape [27]. In 1989 the MSI values for all land cover tended to be high, even reaching 3 , indicating an 
Table 4. Fragstat Result in Delta Kendal in 1989 and 2021

\begin{tabular}{|c|c|c|c|c|c|c|c|c|c|c|c|}
\hline \multirow{2}{*}{ No } & Land Cover & PD (/100 ha) & \multicolumn{2}{|c|}{ ED (m/ha) } & \multicolumn{2}{|c|}{ MSI } & \multicolumn{2}{|c|}{ MNN (m) } & \multicolumn{2}{c|}{ IJI (\%) } \\
\cline { 3 - 13 } & & 1989 & 2020 & 1989 & 2020 & 1989 & 2020 & 1989 & 2020 & 1989 & 2020 \\
\hline 1 & Rice field & 0,050 & 0,099 & 3,713 & 25,677 & 2,286 & 0,115 & 655,73 & 199,07 & 63,331 & 32,025 \\
\hline 2 & Building & 0,034 & 0,065 & 3,481 & 1,146 & 3,267 & 0,316 & 1206,76 & 684,89 & 80,895 & 65,202 \\
\hline 3 & Field & 0,127 & 0,065 & 9,177 & 2,082 & 1,936 & 0,231 & 402,47 & 1061,33 & 36,161 & 72,315 \\
\hline 4 & Shrubs & 0,016 & 0,040 & 0,353 & 0,617 & 1,372 & 0,276 & 6488,45 & 1726,63 & 64,560 & 40,575 \\
\hline 5 & Pond & 0,006 & 0,028 & 0,739 & 4,439 & 2,088 & 0,084 & 421,02 & 271,71 & 55,518 & 85,759 \\
\hline 6 & Forest Mix & 0,124 & 0,105 & 8,692 & 2,737 & 2,082 & 0,302 & 520,14 & 838,98 & 50,970 & 55,604 \\
\hline 7 & Mangrove & 0,037 & 0,046 & 3,706 & 0,835 & 1,856 & 0,265 & 1585,05 & 403,85 & 84,416 & 68,548 \\
\hline 8 & Settlement & 0,037 & 0,254 & 1,876 & 25,342 & 1,443 & 0,210 & 293,35 & 323,94 & 60,372 & 30,985 \\
\hline 9 & Barren & 0,028 & 0,040 & 18,053 & 0,817 & 2,969 & 0,263 & 225,02 & 786,66 & 68,078 & 67,711 \\
\hline
\end{tabular}

irregular land cover structure. Land cover is still dominated by productive land and settlements and there is no urbanization phenomenon. In 2021 the MSI value, in general, decreased due to changes in land structure to become more regular due to urban planning and urbanization.

The MNN value indicates the level of land cover spatial isolation and is an indicator of landscape connectivity. The higher the MNN value, the higher the level of spatial isolation between patches. Shrub's land cover in 1989 had the highest MNN value, which was 6588.4 meters, then it decreased significantly to 1726,635 in 2021. This was due to a significant reduction in land area due to the conversion of land to built-up land. The land cover that experienced an increase in the MNN value was the field from 402.46 in 1989 to 1061.326 in 2021. This increase indicates an increase in spatial isolation due to a significant reduction in land area and land fragmentation.

IJI is an indicator of land fragmentation stating the level of land cover interspersion. In general, the IJI value in 2021 is lower than in 1989. This indicates that the degree of spatial intermixing between patches has decreased. The highest level of interspersion was found in the mangrove forest land cover in 1989, which was $84.4 \%$. Meanwhile, the lowest interspersion rate was found in dryland cover/fields in 1989 at $36.1 \%$. Based on the calculation results, it can also be seen that land cover that has a relatively high patch density tends to have a high level of interference, and vice versa. In general, there is a relationship if there is an increase in the value of PD and ED, there will be a decrease in the value of MNN and IJI and vice versa.

Overall, it shows that every land cover in the Delta Kendal undergoes structural changes. The largest land cover change occurred in the residential land cover, from $30.67 \mathrm{~km} 2$ in 1989 to $64.5 \mathrm{~km} 2$ in 2021 . The rapid growth of settlements was influenced by the development of KIK and the construction of the Semarang-Batang Toll Road. The development of industry triggers an increase in population density due to the increase in migrant workers entering Kendal Regency due to factors that attract employment opportunities. In addition, the presence of the Semarang-Batang Toll Road can increase the potential for land-use change [28]. The use of agricultural and non-agricultural land will turn into toll roads and trigger changes in agricultural land to non-agricultural areas around toll roads due to the increase in population. Access development tends to support economic activities and open transportation links between regions so that it becomes a factor that attracts residents to settle in Kendal Regency. Residents who settle down definitely need a place to live so that the development of settlements in the Kendal Regency becomes more rapid.

\section{Conclusion}

The land cover pattern of the Kendal Delta in 1989 showed that the land cover was dominated by vegetation cover in the form of rice fields, fields, forest mix and shrubs, while in 2020 the land cover in the Kendal Delta experienced a change, namely from the dominance of vegetation cover developing into built-up land such as settlements and buildings.

The quantification of the Kendal delta landscape structure was carried out using patch density (PD), edge density (ED), mean shape index (MSI), mean nearest neighbor $(\mathrm{MNN})$, and interspersion and juxtaposition index (IJI). Based on the overall calculation results indicate that every land cover in the Kendal delta undergoes structural changes. Rice field and settlement land cover increased in PD and ED values and decreased MNN values. This is due to the increase in land settlement sporadically and the fragmentation of paddy fields. Field land cover, forest mix decreased PD and ED values and increased MNN values. This is due to a significant reduction in land area.

Based on the calculation results, it can also be seen that land cover that has a relatively high patch density tends to have a high level of interference, and vice versa. In general, there is a relationship if there is an increase in the value of PD and ED, there will be a decrease in the value of MNN and IJI.

\section{References}

1. R. H. Dauhari, Prinsip-Prinsip Penataan Ruang Laut Pesisir dan Pulau-Pulau Kecil, Makalah 
Seminar Nasional Kelautan Ikatan Mahasiswa Geodesi, Institut Teknologi Bandung (2001)

2. Bappeda Kabupaten Kendal, Rencana Terpadu dan Program Investasi Infrastruktur Jangka Menengah (RPI2JM) Bidang Cipta Karya Kabupaten Kendal 2016-2020 Bab V, Badan Pembangunan Daerah Kabupaten Kendal (2015)

3. K. Kusrini, S. Suharyadi, S. R. Hardoyo, Perubahan Penggunaan Lahan dan Faktor yang Mempengaruhinya di Kecamatan Gunungpati Kota Semarang, Majalah Geografi Indonesia, 25(1), 2540 (2011)

4. K. I. Aulia, S. Subiyanto, B. Sudarsono, Analisis Arah Perkembangan Fisik Wilayah Kabupaten Kendal Menggunakan Sistem Informasi Geografis, Jurnal Geodesi Undip, 8(1), 486-495 (2019)

5. U. M. Lumbanbatu, Perkembangan Dataran Pantai (Coastal Plain) Daerah Kendal Provinsi Jawa Tengah, Jurnal Geologi dan Sumberdaya Mineral, 19(4), 225-237 (2009)

6. T. B. Sanjoto, Perubahan Spasial Delta Sungai Bodri Sebagai Basis Zonasi Tata Ruang Pesisir Kabupaten Kendal, Doctoral dissertation, Program Pascasarjana Undip (2012)

7. Sriyanto, S. Sanjoto, Tjaturahono, Arahan Komoditas Unggulan Perikanan Tambak di Pesisir Kabupaten Kendal (Evaluasi Kesesuaian Lahan Budidaya Perikanan Tambak), Jurnal Geografi (Media Pengembangan Ilmu dan Profesi Kegeografian, 14(2), 66-74 (2018)

8. U. Walz, Landscape structure, landscape metrics and biodiversity, Living Reviews in Landscape Research, 5(3), (2011)

9. J. A. Kupfer, Landscape ecology and biogeography: Rethinking landscape metrics in a Post-Fragstats landscape, Progress in Physical Geography, 36(3), 400-420 (2012)

10. A. Wijaya, Analisis Dinamika Pola Spasial Penggunaan Lahan Pada Wilayah Terdampak Kenaikan Muka Air Laut Di Kota Pekalongan, Institut Teknologi Sepuluh Nopember Surabaya (2017)

11. H. Han, C. Yang, J. Song, Scenario simulation and the prediction of land use and land cover change in Beijing, China, Sustainability, 7(4), 4260-4279 (2015)

12. D. W. Wardani, P. Danoedoro, B. Susilo, Kajian perubahan penggunaan lahan berbasis citra penginderaan jauh resolusi menengah dengan Metode Multi Layer Perceptron dan Markov Chain, Majalah Geografi Indonesia, 30(1), 9-18 (2016)

13. Y. C. Liang, Y. Zeng, E. C. Peh, A. T. Hoang, Sensing-throughput tradeoff for cognitive radio networks. IEEE transactions on Wireless Communications, 7(4), 1326-1337 (2008)

14. A. R. Darmawan, N. Puspaningsih, M. B. Saleh, Kajian Perubahan Tutupan Lahan dengan Menggunakan Metode Multi Layer Perceptron dan
Logistic Regression Di Taman Nasional Gunung Ciremai (2018)

15. B. Bhatta, Analysis of Urban Growth and Sprawl from Remote Sensing Data, Canada: Springer (2010)

16. E. Gökyer, Understanding Landscape Structure Using Landscape Metrics. Advances in Landscape Architecture (2013)

17. E. Uuemaa, M. Antrop, J. Roosaare, R. Marja, Ü. Mander, Landscape metrics and indices: an overview of their use in landscape research, Living reviews in landscape research, 3(1), 1-28 (2009)

18. K. McGarigal, B. J. Marks, FRAGSTATS: Spatial Pattern Analysis Program for Quantifying Landscape Structure, General Technical Report (GTR) (1995)

19. Dinas Pekerjaan Umum, Penyusunan Rencana Terpadu dan Program Investasi Infrastruktur Jangka Menengah (RPI2JM), Bidang Cipta Karya Kabupaten Kendal 2016-2020 (2016)

20. E. C. F. Bird, O. S. Ongkosongo, Environmental changes on the coasts of Indonesia, UNU (1980)

21. M. Ramdhan, Patch Analysis Menggunakan Fragstat (Studi Kasus Area Jambi), Kementerian Kelautan dan Perikanan (2015)

22. H. Han, C. Yang, J. Song, Scenario simulation and the prediction of land use and land cover change in Beijing, China, Sustainability, 7(4), 4260-4279 (2015)

23. M. N. Sadewo, I. Buchori, Simulasi perubahan penggunaan lahan akibat pembangunan kawasan industri kendal (KIK) berbasis cellular automata, Majalah Geografi Indonesia, 32(2), 142-154 (2018)

24. D. R. Setianingrum, A. Suprayogi, Analisis Kesesuaian Lahan Tambak Menggunakan Sistem Informasi Geografis (Studi Kasus: Kecamatan Brangsong, Kabupaten Kendal, Provinsi Jawa Tengah), Jurnal Geodesi Undip, 3(2), 69-80 (2014)

25. A. A. Awanis, S. B. Prayitno, V. E. Herawati, Kajian Kesesuaian Lahan Tambak Udang Vaname Dengan Menggunakan Sistem Informasi Geografis Di Desa Wonorejo, Kecamatan Kaliwungu, Kendal, Jawa Tengah, Buletin Oseanografi Marina, 6(2), 102-109 (2017)

26. L. B. Prasetyo, Pendekatan Ekologi Lanskap Untuk Konservasi Biodiversitas, Bogor: Fakultas Kehutanan Institut Pertanian Bogor (2017)

27. A. W. Wijaya, A. P. Wijaya, A. I. Rahmawati, E. Paryani, H. D. Lestari, I. Amri, L. Ardianti, S. R. Putri, E. Haryono, Analisis Ekologi Bentanglahan di Taman Nasional Baluran dan Sekitarnya, Majalah Geografi Indonesia, 34(1), 34-42 (2020)

28. A. Z. A. Tyo, B. Sudarsono, F. J. Amarrohman, Analisis Kesesuaian Perubahan Penggunaan Lahan Terhadap Rencana Tata Ruang Wilayah (RTRW) di Kecamatan Ngaliyan Pasca Pembangunan Jalan Tol Semarang-Batang. Jurnal Geodesi Undip, 10(1), 11-20 (2020) 